\title{
A study on presence of bioactive compounds in snail Achantina fulica
}

\section{G. V.Zodape}

Department of Zoology, S. S. and L.S. Patkar College of Arts and Science and V. P. Varde College of Commerce and Economics S.V. Road, Goregaon (West), Mumbai- 400062 (Maharashtra), INDIA

E-mail: gautamvz5@yahoo.com

Abstract: The bioactivity study of the crude extract as well as the pure compounds isolated by preparative TLC, of the snail were carried on bacteria, Escherichia coli PBR 322, Vibrio cholerae and cockroaches Periplanata americana. The growth of the bacteria was found to be inhibited and the cockroaches in moribund condition were found to be dead after a period of $24 \mathrm{hrs}$ of incubation. The results concluded that the extract of the snail contained the bioactive compounds.

Keywords: Snail, Bioactive compound, Escherichia coli, Vibrio cholerae, Periplanata americana, Achantina fulica

\section{INTRODUCTION}

Natural products, whether based on microbial, plant, terrestrial animals, marine organisms or other origins have prone to be a rich source of lead compounds in drug discovery Faulkner (2002). Venomous animals offer an enormous additional potential. Currently, more than 100000 venomous animal species are reported, covering almost all phyla (snakes, scorpions, spiders, cone snails, hymepters, sea anemones, jellyfishes and even some lizards, birds and fishes) each of them is characterized by a unique venom compound of hundreds of bioactive molecules (Sonja et al., 1995 and Clifford et al., 2003). These components have evolved and are optimized by nature through million of years to catch and digest preys or for protection against predators Halvorson (1998). The collection, identification and evaluation of bioactive compounds from terrestrial organisms are one of the active fields of research in biological study at present (Carte et al., 1994). The experimental approach consists of a systematic investigation about the action of crude or purified extract on physiological preparations or whole animals to outline the profile of their biological activities and mechanism of action. The present work has been undertaken for isolation and purification of bioactive compounds and action of the extracts of the snail for its biological activity on bacteria and cockroach Periplanata americana.

\section{MATERIALS AND METHODS}

Snail Achantina fulica, were collected from the garden area of Patkar College Goregaon (West), Mumbai during the monsoon season and acclimatized for 2 days at room temperature before use. Pure culture of bacteria, Escherichia coli PBR 322, Vibrio cholerae, were collected from Bhavans National Research Center, Andhari, Mumbai and stored in a refrigerator at $2-8^{\circ} \mathrm{C}$ till their use. Cockroaches Periplanata americana were collected from the drain of Goregaon, nearPatkar College Goregaon (west), Mumbai, and acclimatized at room temperature for $2 \mathrm{hrs}$ before their use by using the standard methods (Pelczar et al., 1993 and APHA, 1999).

The nutrient media was prepared by dissolving $5 \mathrm{~g}$ of peptone, $3 \mathrm{~g}$ beef extract, $8 \mathrm{~g}$ sodium chloride and $150 \mathrm{~g}$ agar in about $800 \mathrm{ml}$ of water and adjusting the $\mathrm{pH}$ of the solutions to 7.3 by drop wise addition of $1 \mathrm{~N}$ sodium hydroxide. The solution was heated 2-3 minutes, cooled and diluted to 1 litre with distilled water. All the apparatus such as syringes, pipettes, conical flasks, Petri dishes and the nutrient media were sterilized in an autoclave before their use.

Chem. Tech. TLC model of HPTLC available at Ancrom test lab. Mulund, Mumbai was used for the analysis of the samples. In this system stationary phase was precoated with aluminum plate containing silica gel $(60$ $\mathrm{F}_{254}$ ), where as the mobile phase a mixture was containing butanol: methanol: water $(3: 1: 1 \mathrm{v} / \mathrm{v})$. The development of the sample spots were done using twin trough chamber. The Deutorium lamp at $254 \mathrm{~nm}$ was used for densitometric scanning of the samples.

All chemicals and solvents used were of analytical grade supplied by M/S S.D. fine chemicals, Thane, (India).

Preparation of crude extract: Finely crushed snail was homogenized with a mixture of $80 \%$ methanol and $1 \%$ acetic acid by heating in water bath at $60^{\circ} \mathrm{C}$ for half an hrs. The process was repeated with more amount of methanol-acetic acid mixture $(5 \mathrm{ml})$ thrice. The supernatant solution was decanted of and centrifuged at $3000 \mathrm{rpm}$ for 20 minutes. The residue settled if any of rejected and the 
clear supernatant solution was placed in a separating funnel and extracted with dichloromethane to defated the solution. The upper clear defated aqueous solution was taken in a beaker and heated on a water bath $40-45^{\circ} \mathrm{C}$ till solid obtained. This solid was weighed and dissolved in $1 \%$ aqueous Tween- 80 solution such that the concentration of the solution corresponds to $1 \mathrm{mg} / \mathrm{ml}$ and stored in screw capped vials in a refrigerator at $-20^{\circ} \mathrm{C}$ till further use (Vankateshwaran, 1997).

I solation of compoundsfrom the crude extract: $5 \mathrm{ml}$ of the crude extract was spotted on a TLC plate coated with silica gel (thickness $0.5 \mathrm{~mm}$ ), dried and kept in the saturated twin trough chamber containing butanol :methanol: water in the ratio of $3: 1: 1(\mathrm{v} / \mathrm{v})$ as a mobile phase and developed up to $9 \mathrm{~cm}$ length. The plate was removed and dried. The development of the sample spots were done using twin trough chamber. The Deutorium lamp at $254 \mathrm{~nm}$ was used for densitometric scanning of the samples. The two spots were obtained. The spots were scrapped off and dissolved in methanol and filtered and evaporated to dryness to get pure compounds.

\section{RESULTS AND DISCUSSION}

The species of snail Achantina fulica, were collected from the garden area of Patkar College Goregaon (West), Mumbai were found to belong to gastropoda class.

E ffect on bacter ia: 10-12 ml of sterilized nutrient medium was placed in each of the sterile petridishes. The pure culture of bacteria Escherichia coli PBR 322, Vibrio cholerae were transferred in to the petridishes by streaking method using a nichrome wire loop. By disc diffusion method $10 \mu \mathrm{l}$ of the crude methanolic extract solution and each of the two compounds isolated on TLC was added separately to the respective petridishes and placed in inoculation chamber adjusted at $37^{\circ} \mathrm{C}$. The growth of bacteria was obtained after $24 \mathrm{hrs}$ of incubation. It was found that the growth of bacteria Escherichia coli PBR 322, Vibrio cholerae was inhibited due to the presence of some bioactive compounds in the crude extract as well as with the compounds isolated on TLC. (Table 1) It was found that Escherichia coli PBR 322 shows more zone of inhibition, than the Vibrio cholerae in crude extract as well as the compound isolated on TLC from the snail.

The similar results were found by (Yasushi et al., 1985). The antibacterial factor from the body surface of the
African giant snail, Achatina fulica Ferussac, was isolated by DEAE-Toyopearl 650M ion exchange chromatography. The isolated preparation exhibited highly positive antibacterial activity both for the Grampositive bacteria. Bacillus subtilis and Staphylococcus aureus and for the Gram-negative bacteria, Escherichia coli and Pseudomonas aeruginosa, but it lost such activity when heated at $75^{\circ} \mathrm{C}$ for $5 \mathrm{~min}$.

E ffect on cock roaches Periplaneta americana: Each of 10 cockroaches was taken in four different chambers of size $(22 \mathrm{X} 12 \mathrm{X} 9 \mathrm{cms}) .10 \mu \mathrm{l}$ of the extract / methanolic solution of the compounds isolated on TLC were injected in the thorax of the each cockroach in the first three glass chambers, the fourth glass chamber was kept as control and no extract was injected in it. The mouth of all the chambers were closed by mosquito net and mortality was noted till $24 \mathrm{hrs}$ of injection.

Cockroaches showed cleaning behavior at the initial stages of poisoning by rubbing their bodies with their legs or sides of the cages. Marentric movements of the mouth parts were also observed and at the later stages of poisoning tremors, incoordination and convulsion leading to paralysis were noted. Cockroaches in moribid condition were found to be dead after $24 \mathrm{hrs}$.

More than 2600 scientific studies have been carried out over the last 20 years testify to the important contribution of toxins extracted from gastropod snails to medicine and cellular biology (Pickrell, 2003). A team from the University of Melborne extracted the conotoxin from a cone-shell snail. They found that it not only inhibits pain as being 10000 times more powerful than morphine, but also accelerates the recovery of injured nerves (Holmes, 2002). The conus species have evolved deadly nerve toxins and small, conformationally constrained peptides of 10 30 amino acids. The conotoxin extracted from cons snail have valuable probes in physiological and pharmacological studies (Myers et al., 1993). Dolastatin, a cytotoxin peptide from Dolabell auricularia is an antineoplastic substance (Pettit et al., 1989). UlapualidaA, a sponge derived macrolide isolated from the nudibranch Hexabranchus Sanguineus exhibits cytotoxic activity against L 1210 murine leukemia and cells and antifungal activity, which exceeds that of clinically useful amphotericin-B (Rorsener and Scheuer, 1986). Chromodorolida-A isolated from Chromocloris

Table 1. Effect of crude extract and the compound isolated on TLC (Fraction one and two) showing zone of inhibition (in millimeters).

\begin{tabular}{lccc}
\hline & Control & Escherichia coli PBR 322 & Vibrio cholerae \\
\hline Crude extract & & Zone of inhibition & $16 \mathrm{~mm}$ \\
TLC Fraction -1 & $00 \mathrm{~mm}$ & $21 \mathrm{~mm}$ & $18 \mathrm{~mm}$ \\
TLC Fraction -2 & $00 \mathrm{~mm}$ & $28 \mathrm{~mm}$ & $23 \mathrm{~mm}$ \\
\hline
\end{tabular}


cavae exhibit in vitro antimicrobial and cytotoxic activities.

\section{Conclusion}

The species of snail Achantina fulica, contained two compounds. The extract of the whole snail in $80 \%$ methanol and $1 \%$ acetic acid and the methanolic solution of each of the two compounds isolated on TLC showed an inhibition of growth of bacteria Escherichia coli PBR 322 , Vibrio cholerae indicating the presence of antibacterial compounds. The percent mortality of the cockroaches was found to be $100 \%$ when the cockroaches were fed with the extract of the snail and the methanolic solution of the compounds indicating the presence of bioactive compounds in the snail.

\section{REFERENCES}

APHA (1999). Standard methods of the examination of water and west water, $20^{\text {th }}$ Edn, Washington, D.C.; American Public Health Association / American Water Works Association / Water Environment Federation.

Carte, B. K., Chan, G., Freyer, A., Hemling. M.E., Compagone, R.S. and Faulkner, D.J. (1994). Pentatheipins and trithianes from two Lissoclinum species and a E udistoma sp.; Inhibitors of protein kinase c. Tetrahedron, 50: 12785-12792.

Clifford Kavan T., Gross Liaini, Johnson Kwame, Martin Khali J, Shaheen Nagma and Harrington Melissa, A. (2003). Slimetrail tracking in the predatory snail, Euglandina rosea. Behavioral N eur oscience, 117 (5): 1086-1095

Faulkner, D.J. (2002). Marine natural products, Nat. Prod. Res. , 19, 1-48.
Halvorson, H.O. (1998). Aquaculture, marine sciences and oceanography: A confluence connection. N ew E ngl.J .H igher Ed. E con. Dev., $13: 28-42$

Holmes, I. (2002). Snail toxin could ease chronic pain.Nature Science Update. March 29.(http://www.manandmollusc.net/ links_medicine.html)

Vankateshwaran, K. (1997). Microchemolytic assay P-41-42. In: Laboratory manual on advanced Techniques in marine Biotoxinology (Venka K. and Pani Prasad K. Ed) CAS in Fishery science. CIFE Mumbai India: p-76.

Pelczar, M. J.(1993). Text book of microbiology. $5^{\text {th }}$ edition, Tata McWell Hill publication.

Myers, P.A., Cruz,L.Z., Rivier,J.E. and Olivera,B.M.(1993). Conus peptide as chemical probes for receptors and ion channels. Chem.Rev., 93:1923-1936.

Pettit,G.R.,Singh,S.B.,Hogan,F.,Loyd-Williams,P. Herald,C.L., Burbett, D.D. and Clewlow,P.J.(1989). The absolute configuration and synthesis of natural(-)-dolostatinio. J . Am Chem. Soc., 70,5463-5465.

Pickrell, J. (2003). Wonder Drug Snails face threats, Expers warn. National Geographic News. 1-2 (http:// news.nationalgeographic.com/news/2003/10/ 1016_031016_conesnail.html.

Rorsener, J.A. and Scheuer, P.J. (1986).Ulapualids A and $\mathrm{B}$, extraordinary antitumor macrolides from nudibranch egg masses. J . Am C hem Soc., 108:846-847

Sonja Hesbacher, Bruno Baur, Anette Baur and Peter Proksch (1995). Sequesterian of lichen compounds by three species of terrestrial snails: J ournal of Chemical E cology. 21 (2): 21

Yasushi Kubota, Youichi Watanabe, Hisako Otsuka, Toru Tamiya, Takahide Tsuchiya and Juichiro J. Matsumoto; (1985), Purification and characterization of an antibacterial factor from snail mucus. Comparative Pharmacology. 82 ( 2) : 345-348. 